\title{
INTERCROPPING OF CARROT X COWPEA-VEGETABLES: EVALUATION OF CULTIVAR COMBINATIONS FERTILIZED WITH ROOSTERTREE ${ }^{1}$
}

\author{
ARNALDO PANTOJA DA COSTA ${ }^{2}$, FRANCISCO BEZERRA NETO ${ }^{3 *}$, MAIELE LEANDRO DA SILVA $^{4}$, JAILMA \\ SUERDA SILVA DE LIMA ${ }^{3}$, AURÉLIO PAES BARROS JÚNIOR ${ }^{3}$, VÂNIA CHRISTINA NASCIMENTO PORTO ${ }^{3}$
}

\begin{abstract}
This study aimed to evaluate combinations of cowpea-vegetable cultivars with carrot cultivars in a strip-intercropping system fertilized with roostertree. The work was conducted at the Experimental Farm "Rafael Fernandes" of the Universidade Federal Rural do Semi-Árido (UFERSA) during September 2013 to March 2014. The experimental design was a randomized complete block with four replications and treatments arranged in a factorial $4 \times 2$ scheme, resulting from the combination of four cowpea-vegetable cultivars (BRS Tumucumaque, BRS Cauamé, BRS Guariba and BRS Itaim) with two carrot cultivars (Brasilia and Alvorada). The characteristics evaluated in cowpea-vegetables were: number of green pods per area, productivity and dry weight of green pods, number of grains per pod, productivity of grains, weight of 100 grains, and dry weight of green grains. In the carrot cultivars, we evaluated total, commercial, and classified productivity of roots. The cultivar combinations were evaluated in terms of land equivalent ratio, productive efficiency index, score of the canonical variable, as well as indicators of gross and net income, rate of return, profit margin, and modified monetary advantage. The intercropping system using the cultivars BRS Guariba (cowpea) and Alvorada (carrot) achieved highest agronomic/biological efficiency. Highest economic efficiency was achieved with the combination BRS Tumucumaque (cowpea) and Brasilia (carrot).
\end{abstract}

Keywords: Daucus carota. Vigna unguiculata. Calotropis procera. Intercropping. Agronomic/biological and economic efficiency.

\section{CONSÓRCIO DE CENOURA X CAUPI-HORTALIÇA: AVALIAÇÃO DE COMBINAÇÕES DE CULTIVARES ADUBADAS COM FLOR-DE-SEDA}

\begin{abstract}
RESUMO - Este estudo teve como objetivo avaliar combinações de cultivares de caupi-horaliça com cultivares de cenoura em sistema consorciado em faixas adubadas com flor-de-seda. $\mathrm{O}$ trabalho foi conduzido na Fazenda Experimental "Rafael Fernandes" da Universidade Federal Rural do Semi-Árido (UFERSA), durante o período de setembro de 2013 a março de 2014. O delineamento experimental utilizado foi o de blocos completos casualizados com 4 repetições e os tratamentos arranjados em esquema fatorial 4 x 2 , resultante da combinação de quatro cultivares de caupi (BRS Tumucumaque, BRS Cauamé, BRS Guariba e BRS Itaim) com duas cultivares de cenoura (Brasília e Alvorada). As características avaliadas no caupi-hortaliça foram: número de vagens verdes por área, produtividade e peso seco de vagens verdes, número de grãos por vagem, produtividade de grãos, peso de 100 grãos e peso seco de grãos verdes. Nas cultivares de cenoura foram avaliadas: as produtividades total, comercial e classificada de raízes. As combinações de cultivares foram avaliadas pelo índice de uso eficiente da terra, índice de eficiência produtiva, escore da variável canônica e pelos indicadores rendas bruta e líquida, taxa de retorno, índice de lucratividade e vantagem monetária corrigida. O sistema de consórcio utilizando as cultivares de caupi BRS Guariba e a de cenoura Alvorada obteve maior eficiência agronômica/biológica. A maior eficiência econômica foi obtida com a combinação de caupi BRS Tumucumaque e cenoura Brasília.
\end{abstract}

Palavras-chave: Daucus carota. Vigna unguiculata. Calotropis procera. Associação de culturas. Eficiência agronômica/biológica e econômica.

\footnotetext{
*Corresponding author

${ }^{1}$ Received for publication in $05 / 02 / 2016$; accepted in $12 / 20 / 2016$.

Paper extracted from the doctoral thesis of the first author.

${ }^{2}$ Department of Educational Development, Instituto Federal de Educação Ciência e Tecnologia do Pará, Castanhal, PA, Brazil; arnaldo.pantoja2@hotmail.com.

${ }^{3}$ Department of Plant Sciences, Universidade Federal Rural do Semi-Árido, Mossoró, RN, Brazil; bezerra@ufersa.edu.br, jailma@ufersa.edu.br, aurelio.barros@ufersa.edu.br, vania@ufersa.edu.br.

${ }^{4}$ Department of Agronomy, Universidade Estadual de Mato Grosso do Sul, Aquidauana, MS, Brazil; maiele_engenharia@yahoo.com.br.
} 


\section{INTRODUCTION}

Intercropping of vegetables is a common practice in the northeast of Brazil; especially in the state of Rio Grande do Norte, and generally increases yields and profits. It therefore allows maximum use of environmental resources and promotes ecological balance (MONTEZANO, PEIL, 2006).

In intercropping, the cultures involved are not necessarily sown at the same time, but mostly cultivated simultaneously, promoting an interaction. It is therefore crucial to select crops which exert complementarity to some extent. This is possible when the species have different ecological niches and can thus maximize light use and the absorption of water and nutrients (GRANGEIRO et al., 2007).

The efficiency of intercropping depends directly on the cultivars used and the intercropping system. A major challenge for the success of this method is the determination of potential cultivar combinations and their management, especially in terms of maximizing area use and considering producer interests (ALMEIDA et al., 2015). For example, lettuce cultivars and arugula were intercropped with carrot, and the combination of the lettuce cultivar 'Tainá' with the arugula cultivar 'Cultivada' or 'Folha Larga' resulted in highest agronomic and economic efficiency (BEZERRA NETO et al., 2012).

Intercropping of cowpea-vegetables with root vegetables such as carrot is increasingly implemented; however, information about viability, profitability and postharvest quality is scarce. Cowpea (Vigna unguiculata (L.) Walp) is a major legume grown in semi-arid regions of northeastern Brazil. Is it rich in iron and protein and the green pods are consumed. The beans constitute the raw material of a range of regional dishes besides being used as green manure (FROTA, 2008; SANTOS et al., 2009). When grown for consumption of fresh grains, the species is treated as a vegetable crop, hence the name "cowpea-vegetable" (ROCHA, 2009).

More information on intercropping of cowpea-vegetable with root vegetables as a function of factors-production such as cultivars of the component cultures, among others, is needed. In addition, more effective management strategies need to be developed to increase agro-economic viability of these intercropping systems. Therefore, the aim of this study was to evaluate combinations of cowpea-vegetable cultivars with carrot cultivars in strip-intercropping systems.

\section{MATERIAL AND METHODS}

The study was conducted from September
2013 to March 2014 at the Rafael Fernandes farm of the Universidade Federal Rural do Semi-Árido (UFERSA). The area is located in the Alagoinha district, $20 \mathrm{~km}$ from the county seat Mossoró ( $5^{\circ} 11^{\prime} \mathrm{S}$ and $37^{\circ} 20^{\prime} \mathrm{W}, 18 \mathrm{~m}$ altitude). The climate is semi-arid and classified as "BShw", dry and very hot, according to Koppen. There are two distinctive seasons: the dry season from June to January and the rainy season from February to May (OLIVEIRA, 2012). During the experimental period, minimum, average, and maximum temperatures were 25,27 , and $31^{\circ} \mathrm{C}$, respectively; relative humidity was $66 \%$, with a wind speed of $4 \mathrm{~m} \mathrm{~s}^{-1}$, solar radiation of 918 $\mathrm{kjm}^{2}$, rainfall of $0 \mathrm{~mm}$, atmospheric pressure of $1,011 \mathrm{hPa}$, and average temperature of the dew point of $19^{\circ} \mathrm{C}$.

The soil of the experimental area was classified as Oxisol dystrophic (EMBRAPA, 2006). Prior to the experiment, soil samples at a depth of $0-20 \mathrm{~cm}$ were taken using a Dutch auger and homogenized to obtain a composite sample. Analysis was performed at the Laboratory of Soil Fertility and Nutrition of the Department of Environmental Sciences and Technology of Plants of the UFERSA, with the following results: $\mathrm{pH}$ (water) $=7.09$,

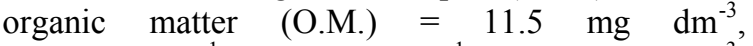
$\mathrm{N}=0.04 \mathrm{~g} \mathrm{~kg}^{-1}, \mathrm{P}=15.14 \mathrm{~g} \mathrm{~kg}^{-1}, \mathrm{~K}=50.5 \mathrm{mg} \mathrm{dm}^{-3}$, $\mathrm{Na}=4.1 \mathrm{mg} \mathrm{dm}{ }^{-3}, \mathrm{Ca}=1.84 \mathrm{cmol}_{\mathrm{c}} \mathrm{dm}^{-3}$, $\mathrm{Mg}=1.39 \mathrm{cmol}_{\mathrm{c}} \mathrm{dm}^{-3}$, and CTC $=3.38 \mathrm{cmol}_{\mathrm{c}} \mathrm{dm}^{-3}$.

The experimental procedure was a randomized complete block design, with treatments arranged in a factorial $4 \times 2$ scheme with four replications. The first factor constituted the cultivars of cowpea-vegetable (BRS Itaim, BRS Tumucumaque, BRS Guariba, and BRS Cauamé) and the second the carrot cultivars (Brasília and Alvorada). The population of plants recommended for these vegetables in single culture in this region is 200,000 plants per hectare for cowpea-vegetable (EMBRAPA, 2009) and 500,000 plants per hectare for carrot (BEZERRA NETO et al., 2007).

The intercropping system was established in alternating strips of the component crops in a proportion of $50 \%$ of the area for carrot and $50 \%$ of the remaining area for the cowpea-vegetable, where each plot consisted of four carrot rows alternated with four rows of cowpea-vegetable, flanked by two carrot border rows on one side and two border rows of cowpea-vegetable on the other side, thereby constituting the side borders. The total area of the plot was $3.6 \mathrm{~m}^{2}$, with a harvest area of $2.00 \mathrm{~m}^{2}$, containing 40 cowpea-vegetable plants with a spacing of $0.25 \mathrm{~m}$ between rows with 10 plants per meter and of 100 carrot plants with a spacing of $0.25 \mathrm{~m}$ between rows with 25 plants per linear meter. In the intercropping system, we used the same population size as in the monocropping.

In each block, single plots of the crops cowpea-vegetable and carrot were planted to obtain the efficiency indices of each cultivar and 
intercropped system. The monocrop of each vegetable crop was established by planting six rows per plot, with a total area $3.60 \mathrm{~m}^{2}$ and a harvest area of $2.00 \mathrm{~m}^{2}$, with a spacing of $0.50 \times 0.10 \mathrm{~m}$ for the cowpea-vegetable. Total area of the carrot crop was $1.44 \mathrm{~m}^{2}$, with a harvest area of $0.80 \mathrm{~m}^{2}$ and a spacing of $0.20 \times 0.10 \mathrm{~m}$. The harvest area was made up of four central rows of plants, excluding the first and last plants of each row which were used as borders.

Soil preparation consisted of mechanical cleaning of the area with the aid of a tractor with attached plow, followed by harrowing and mechanical lifting of the beds. After this, we carried out a solarization pre-planting with transparent plastic type Vulca Brilho Bril Fles 30 microns for 30 days in order to reduce nematodes, esp. Meloidogyne spp, and plant parasites in the top $0-10 \mathrm{~cm}$ of the soil (see SILVA et al. 2006).

Roostertree material for fertilization was collected from the native vegetation of the urban area Mossoró-Apodi, crushed into pieces of 2-3 cm, and placed to dry at room temperature until it reached the point of hay; it was then stored with a moisture content of $8.3 \%$. Nutrient contents of the green manure were as follows: $15.3 \mathrm{~g} \mathrm{~kg}^{-1} \mathrm{~N}, 4.0 \mathrm{~g} \mathrm{~kg}^{-1} \mathrm{P}$, $15.7 \mathrm{~g} \mathrm{~kg}^{-1} \mathrm{~K}, 9.3 \mathrm{~g} \mathrm{~kg}^{-1} \mathrm{Ca}$, and $7.03 \mathrm{~g} \mathrm{~kg}^{-1} \mathrm{Mg}$, with a carbon/nitrogen ratio of 25: 1 .

Two incorporations of green manure were carried out in plots of intercropping and single crop of carrots, with $50 \%$ of the manure incorporated in all plots in the intercropped beds 20 days before sowing of the intercropping component cultures; the remaining $50 \%$ were incorporated at 45 days after planting carrot (SILVA et al., 2013). Incorporation of green manure in the single cropping of cowpea-vegetable was performed 20 days before planting at $42 \mathrm{t} \mathrm{ha}^{-1}$ and in the carrot of $51 \mathrm{t} \mathrm{ha}^{-1}$, respectively; these amounts have been identified as optimum quantities in previous studies (VIEIRA, 2014; SILVA, 2014). In the intercropping system, the optimum amount was $50.37 \mathrm{t} \mathrm{ha}^{-1}$ (BEZERRA NETO et al., 2013).

Irrigation was performed using a micro-sprinkler, with two daily waterings, one in the morning and another in the afternoon, supplying on average $8 \mathrm{~mm} \mathrm{day}^{-1}$ and maintaining soil moisture between 50 and $70 \%$ of field capacity to provide ideal conditions for nitrification (NOVAIS et al., 2007). Weed control was carried out daily.

On November 20, 2013, sowing of cowpea-vegetable and carrot was performed. Thinning was carried out at twenty-one and eight days after emergence of carrot and cowpea-vegetable, respectively. One week before harvest, we randomly identified 20 plants in each plot for data collection. Cowpea harvest was performed 55 days after sowing through four harvesting sessions, with the last on January 28, 2014. Carrots were harvested at 107 days after sowing.
We evaluated the following characteristics for cowpea: number of green pods per area (quantified as the number of green pods harvested per $\mathrm{m}^{2}$ ), yield of green pods (quantified all pods harvested from plants of the harvest area, expressed in $\mathrm{kg} \mathrm{ha}^{-1}$ ), dry pod weight (obtained from a random sample of 20 plants of the harvest area and expressed in $\mathrm{kg} \mathrm{ha}^{-1}$ ), number of grains per pod (obtained from a sample of 20 plants randomly chosen in the harvest area of each plot), productivity of green grains (determined from the amount of grains from the harvest area of each parcel, expressed in $\mathrm{kg} \mathrm{ha}^{-1}$ ), weight of 100 grains (obtained from four random samples of 100 grains, expressed in g), and dry weight of green grains (obtained from samples of grains from 20 plants, placed in an oven with forced air circulation at $65^{\circ} \mathrm{C}$ until constant mass, expressed in $\mathrm{kg} \mathrm{ha}^{-1}$ ).

For carrot, we evaluated the parameters total productivity (fresh mass of all plant roots of harvest area, expressed in $\mathrm{t} \mathrm{ha}^{-1}$ ) and commercial productivity of roots (obtained from fresh mass of the plant roots of harvest area, free of cracks, bifurcations, nematodes, and mechanical damage, expressed in $\mathrm{t} \mathrm{ha}^{-1}$ ) and classified productivity of roots, calculated by the length and largest diameter: in longs, with a length of 17 to $25 \mathrm{~cm}$ and diameter smaller than $5 \mathrm{~cm}$; in means, with a length of 12 to $17 \mathrm{~cm}$ and a diameter larger than $2.5 \mathrm{~cm}$; in shorts, with a length of $5-12 \mathrm{~cm}$ and a diameter larger than $1 \mathrm{~cm}$, and in scraps, considered the roots that do not fit in the above measures, with cracks, bifurcations, nematodes, and/or mechanical damage (VIEIRA; PERSON; MAKISHIMA, 1997).

The indices of agronomic/biological efficiency of the intercropping systems were determined by the land equivalent ratio (LER), which is defined as the relative area of land under conditions of isolated planting and required to provide productivity values achieved by intercropping (WAKTOLA; BELETE, TANA, 2014). It is calculated using the following expression:

$$
\operatorname{LER}=\left(\mathrm{Y}_{\mathrm{ccv}} / \mathrm{Y}_{\mathrm{cs}}\right)+\left(\mathrm{Y}_{\mathrm{cvc}} / \mathrm{Y}_{\mathrm{cvs}}\right) \text {, }
$$

where: $\mathrm{Y}_{\mathrm{ccv}}=$ commercial productivity of carrot roots in intercropping with cowpea-vegetable, $\mathrm{Y}_{\mathrm{cs}}=$ commercial productivity of carrot roots in single crop, $Y_{\mathrm{cvc}}=$ green grain productivity of cowpea-vegetable in intercropping with carrot, $\mathrm{Y}_{\mathrm{cvs}}=$ green grain productivity of cowpea-vegetable in single cropping.

We obtained LER values for each plot, considering the homogeneous standardization method of the average productivity of repetitions of the cultivars in single cropping over blocks.

In the calculation of the productive efficiency index of each treatment, we used the Data Envelopment Analysis (DEA model with constant returns to the scale, SOARES DE MELLO et al, 2013), since there was no significant difference 
between scales. This model has the following mathematical formulation:

$$
\begin{aligned}
& \operatorname{Max}_{\sum_{j=1}^{s}} u_{j} y_{j o}=1 \\
& \sum_{j=1}^{s} v_{j} y_{j k} x_{i o} \quad \sum_{i=1}^{r} v_{i} x_{i k} \leq 0, \mathrm{k}=1, \ldots, \mathrm{n}
\end{aligned}
$$

$\mathrm{u}_{\mathrm{j}}, \mathrm{v}_{\mathrm{i}} \geq \mathrm{o}, \mathrm{i}=1, \ldots, \mathrm{s}, \mathrm{j}=1, \ldots, \mathrm{r}$,

where $X_{i k}$ is the input $i$ value $(i=1, \ldots, s)$ for treatment $\mathrm{k}(\mathrm{k}=1, \ldots, \mathrm{n}), \mathrm{Y}_{\mathrm{jk}}$ is the output $\mathrm{j}$ value $(\mathrm{j}=1, \ldots, \mathrm{r})$ for treatment $\mathrm{k}$, vi and uj are weights assigned to inputs and outputs, respectively, and $\mathrm{O}$ is the treatment being analyzed.

The evaluation units were the treatments (intercroppings), with eight from the combination of four cowpea-vegetable cultivars (BRS Tumucumaque, BRS Cauamé, BRS Guariba and BRS Itaim) with two carrot cultivars (Brasília and Alvorada). The outputs were the productivities of carrot and cowpea-vegetable. To assess the yield of each plot, it was assumed that each plot used a single resource with a unitary level, following an approach similar to that used previously (SOARES DE MELLO; GOMES, 2004), since the outputs incorporated the possible inputs.

In the modeling of this study, we used the rate of return (index described in the following item) as input.

The score of the canonical variable $(Z)$ was obtained by bivariate analysis of variance of the productivities of cowpea-vegetable and carrot.

The economic indicators used to evaluate the intercropping systems were:

-Gross return (GR), obtained through the value of the production per hectare and based on price paid to producers in the region in March 2014. For carrot, the amount paid was $\mathrm{R} \$ 0.80 \mathrm{~kg}^{-1}$ and for cowpea-vegetable, it was $\mathrm{R} \$ 6.00 \mathrm{~kg}^{-1}$. Updating the change of the US dollar against the Brazilian real, its value was $1 \mathrm{USD}=3.3333 \mathrm{BRL}$ in December 2016 .

-Net return (NR), obtained by the difference between gross return (GR) and total costs (TC) involved. The total cost of production was calculated and determined at the end of the production process in March 2014. The modality of analyzed cost corresponds to the total expenditure per hectare of cultivated area, which covers the services provided by stable capital, i.e. the floating capital contribution and the value of the alternative costs. Alternative costs or opportunity were decided by adopting the interest rate of $6 \%$ per year, equivalent to the gain in savings accounts. For depreciation, we used the straight-line method or fixed quotas, which determines the annual value of depreciation from the useful lifetime of the durable goods of their initial value and scrap. Maintenance and facility costs as well as machinery and equipment inputs directly related to the production were $1 \%$ p.a. of the construction cost value; for the pump and irrigation system, the percentage was $7 \%$ p.a.

- Rate of return (RR), obtained from the ratio between gross return and total cost.

-Profit margin (PM), determined by the ratio between net return (NR) and gross return (GR), expressed as a percentage.

-Modified monetary advantage (MMA), determined by the expression

MMA = NR x (LER - 1)/LER,

where MMA = modified monetary advantage, $\mathrm{NR}=$ net income, $\mathrm{LER}=$ land equivalent ratio.

We performed univariate analysis of variance, using the statistical package SISVAR (FERREIRA, 2011) for a randomized complete block design with treatments arranged in a factorial design. Tukey's test at $5 \%$ probability was used to compare averages of carrot and cowpea cultivars.

\section{RESULTS AND DISCUSSION}

\section{Cowpea-vegetable crop}

There was no significant interaction between cultivars of cowpea-vegetable and carrot in any of the characteristics evaluated in the cowpea-vegetable. However, significant differences between cowpea-vegetable cultivars in sole crops were recorded for the number of green grains per pod and productivity of green pods, with the cultivars BRS Tumucumaque, BRS Guariba, and BRS Cauamé yielding higher values than BRS Itaim for the number of green grains and BRS Tumucumaque obtaining highest productivity of green grains (Table 1). These differences can be attributed to the material architecture, where semi-erect cultivars (BRS Tumucumaque, BRS Guariba and BRS Cauamé) performed better than the erect cultivar (BRS Itaim). According to Matos Filho et al. (2009), plant architecture significantly impacts grain yield and productivity as well as use of environmental resources. Freire Filho et al. (2005) have stated that semi-erect port cultivars produce more than erect port cultivars. 
Table 1. Number of green pods per area (NGP), productivity of green pods (PGP), dry weight of green pods (DWGP), number of green grains per pod (NGGP), productivity of green grains (PGG), weight of 100 grains (W100G), and dry weight of green grains (DWGG) of cowpea-vegetable as a function of cowpea-vegetable and carrot cultivars in intercropping and cowpea-vegetable cultivars in monocropping.

\begin{tabular}{|c|c|c|c|c|c|c|c|}
\hline $\begin{array}{l}\text { Cowpea-vegetable } \\
\text { cultivars intercropped } \\
\text { with carrot }\end{array}$ & $\begin{array}{l}\text { NGP } \\
\left(\mathrm{m}^{2}\right)\end{array}$ & \multicolumn{3}{|c|}{$\left(\mathrm{kg} \mathrm{ha}^{-1}\right)$} & $\begin{array}{c}\text { PGG } \\
\left(\mathrm{kg} \mathrm{ha}^{-1}\right)\end{array}$ & $\begin{array}{c}\text { W100G } \\
(\mathrm{g})\end{array}$ & $\begin{array}{l}\text { DWGG } \\
\left(\mathrm{kg} \mathrm{ha}^{-1}\right)\end{array}$ \\
\hline BRS Itaim & $31.50 \mathrm{a}$ & $819.01 \mathrm{a}$ & $0.287 \mathrm{a}$ & $7.43 \mathrm{a}$ & $289.54 \mathrm{a}$ & $29.31 \mathrm{a}$ & $0.180 \mathrm{a}$ \\
\hline BRS Tumucumaque & $44.75 \mathrm{a}$ & $1200.14 \mathrm{a}$ & $0.460 \mathrm{a}$ & $7.91 \mathrm{a}$ & $431.46 \mathrm{a}$ & $30.88 \mathrm{a}$ & $0.291 \mathrm{a}$ \\
\hline BRS Guariba & $44.75 \mathrm{a}$ & $1022.43 \mathrm{a}$ & $0.440 \mathrm{a}$ & $6.78 \mathrm{a}$ & $336.59 \mathrm{a}$ & $26.67 \mathrm{a}$ & $0.296 \mathrm{a}$ \\
\hline BRS Cauamé & $29.37 \mathrm{a}$ & $825.12 \mathrm{a}$ & $0.315 \mathrm{a}$ & $8.42 \mathrm{a}$ & $300.77 \mathrm{a}$ & $20.62 \mathrm{a}$ & $0.199 \mathrm{a}$ \\
\hline \multicolumn{8}{|c|}{ Cultivars of carrot in intercropping } \\
\hline Brasília & $35.06 \mathrm{a}$ & $902.28 \mathrm{a}$ & $0.347 \mathrm{a}$ & $7.18 \mathrm{a}$ & $309.24 \mathrm{a}$ & $25.80 \mathrm{a}$ & $0.230 \mathrm{a}$ \\
\hline Alvorada & $40.12 \mathrm{a}$ & $1031.07 \mathrm{a}$ & $0.404 \mathrm{a}$ & $8.10 \mathrm{a}$ & $369.94 \mathrm{a}$ & $27.94 \mathrm{a}$ & $0.253 \mathrm{a}$ \\
\hline \multicolumn{8}{|c|}{ Cultivars of cowpea-vegetables in monocropping } \\
\hline BRS Itaim & $56.75 \mathrm{a}$ & $1484.84 \mathrm{ab}$ & $0.527 \mathrm{a}$ & $5.28 \mathrm{~b}^{*}$ & $484.38 \mathrm{a}$ & $35.23 \mathrm{a}$ & $0.367 \mathrm{a}$ \\
\hline BRS Tumucumaque & $63.25 \mathrm{a}$ & $2152.64 \mathrm{a}$ & $0.832 \mathrm{a}$ & $10.21 \mathrm{a}$ & $755.25 \mathrm{a}$ & $32.64 \mathrm{a}$ & $0.517 \mathrm{a}$ \\
\hline BRS Guariba & $44.50 \mathrm{a}$ & $1263.34 \mathrm{~b}$ & $0.525 \mathrm{a}$ & $10.02 \mathrm{a}$ & $434.38 \mathrm{a}$ & $26.80 \mathrm{a}$ & $0.347 \mathrm{a}$ \\
\hline BRS Cauamé & $58.00 \mathrm{a}$ & $1716.03 \mathrm{ab}$ & $0.780 \mathrm{a}$ & $9.93 \mathrm{a}$ & $475.32 \mathrm{a}$ & $27.31 \mathrm{a}$ & $0.527 \mathrm{a}$ \\
\hline CV (\%) & 37.63 & 38.03 & 42.13 & 18.66 & 50.32 & 27.65 & 49.30 \\
\hline
\end{tabular}

*Means followed by different lowercase letters in the column differ statistically by Tukey test at $5 \%$ probability. $\mathrm{CV}=$ coefficient of variation.

Regarding cowpea in intercropping, there was no significant difference in terms of number of green pods per area, productivity of green pods, dry weight of green pods, number of green grains per pod, productivity of green grains, weight of 100 grains, and dry weight of green grains (Table 1). These results show that the intercropping of cowpea-vegetables with carrot presented weak competitiveness between cultivars. Vandermeer (1989) reports that in intercropping, weak competition is given when a species provides some type of benefit to another, thereby positively altering the environment of other species; it also occurs when the two cultures use different components of the environment and therefore occupy different environmental niches.

\section{Carrot crop}

There was a significant interaction between carrot cultivars and cowpea-vegetable cultivars in terms of total and commercial productivities of roots (Table 2). There were no differences in terms of productivity between carrot and cowpea cultivars. In contrast, partitioning the carrot cultivars within each cultivar of cowpea-vegetable showed significant differences between cultivars when associated with the cowpea-vegetable cultivar BRS Tumucumaque in terms of productivity and when associated with the cowpea-vegetable cultivar BRS Cauamé in terms of commercial productivity, with the cultivar Brasília achieving higher values than the cultivar Alvorada (Table 2).

Table 2. Commercial (CP) and total (TP) productivities of carrot roots as a function of cultivars of cowpea-vegetable and carrot in intercropping and monocropping systems.

\begin{tabular}{|c|c|c|c|c|}
\hline \multicolumn{5}{|c|}{ Cultivars of carrot intercropped with cowpea-vegetable } \\
\hline & \multicolumn{2}{|c|}{$\mathrm{CP}\left(\mathrm{t} \mathrm{ha}^{-1}\right)$} & \multicolumn{2}{|c|}{ TP $\left(\mathrm{t} \mathrm{ha}^{-1}\right)$} \\
\hline $\begin{array}{l}\text { Cowpea-vegetable cultivars } \\
\text { intercropped with carrot }\end{array}$ & Brasília & Alvorada & Brasília & Alvorada \\
\hline BRS Itaim & $18.39 \mathrm{aA}$ & $20.80 \mathrm{aA}$ & $19.64 \mathrm{aA}$ & $22.18 \mathrm{aA}$ \\
\hline BRS Tumucumaque & $24.78 \mathrm{aA} *$ & $17.34 \mathrm{aB}$ & $26.27 \mathrm{aA}$ & $18.29 \mathrm{aB}$ \\
\hline BRS Guariba & $22.63 \mathrm{aA}$ & $23.38 \mathrm{aA}$ & $23.72 \mathrm{aA}$ & $24.32 \mathrm{aA}$ \\
\hline BRS Cauamé & $23.98 \mathrm{aA}$ & $18.13 \mathrm{aB}$ & $24.49 \mathrm{aA}$ & $19.33 \mathrm{aA}$ \\
\hline Carrot cultivars in monocrop & $33.02 \mathrm{~A}$ & $27.34 \mathrm{~B}$ & $35.09 \mathrm{~A}$ & $28.05 \mathrm{~B}$ \\
\hline $\mathrm{CV}(\%)$ & \multicolumn{2}{|c|}{16.38} & \multicolumn{2}{|c|}{15.63} \\
\hline
\end{tabular}

*Means followed by different lowercase letters in the column and uppercase letters in the line differ statistically by Tukey's test at $5 \%$ probability.

Significant differences were also recorded between monocropped cultivars of carrot in terms of commercial and total productivities, with the cultivar Brasilia standing out from the cultivar Alvorada (Table 2).
The cultivar Brasília seems to be better adapted to the region than the cultivar Alvorada, showing high productivity when intercropped with BRS Tumucumaque. Similar results have been observed by Bezerra Neto et al. (2013), who studied 
intercropping systems of carrot with cowpea-vegetable. Regarding the monocrop, the productive performance of the cultivar Brasília was superior that of Alvorada, showing greater environmental adaptability according to results obtained by Lopes et al. (2008).
No significant differences were recorded between cultivars of cowpea-vegetable in the carrot productivities of long roots, medium, and scrap and between intercropped carrot cultivars in the productivities of medium roots and scrap and between carrot cultivars in monocropping in the productivities of short and medium roots (Table 3 ).

Table 3. Productivities of long roots (PLR), medium roots (PMR), short roots (PSR), and scrap (PScR) of carrots as a function of cultivars of cowpea-vegetable and carrot in intercropped and monocropped carrot cultivars.

\begin{tabular}{|c|c|c|c|c|}
\hline $\begin{array}{l}\text { Cowpea-vegetable cultivars } \\
\text { intercropped with carrot }\end{array}$ & $\begin{array}{l}\text { PLR } \\
\left(\mathrm{t} \mathrm{ha}^{-1}\right)\end{array}$ & $\begin{array}{c}\text { PMR } \\
\left(\mathrm{t} \mathrm{ha}^{-1}\right) \\
\end{array}$ & $\begin{array}{l}\text { PSR } \\
\left(\mathrm{t} \mathrm{ha}^{-1}\right)\end{array}$ & $\begin{array}{l}\text { PScR } \\
\left(\text { t ha }^{-1}\right) \\
\end{array}$ \\
\hline BRS Itaim & $4.56 \mathrm{a}$ & $11.44 \mathrm{a}$ & $2.34 \mathrm{a}$ & $1.31 \mathrm{a}$ \\
\hline BRS Tumucumaque & $6.76 \mathrm{a}$ & $12.57 \mathrm{a}$ & $1.73 \mathrm{~b}$ & $1.22 \mathrm{a}$ \\
\hline BRS Guariba & $6.60 \mathrm{a}$ & $13.60 \mathrm{a}$ & $2.80 \mathrm{a}$ & $1.01 \mathrm{a}$ \\
\hline BRS Cauamé & $5.02 \mathrm{a}$ & $13.24 \mathrm{a}$ & $2.79 \mathrm{a}$ & $0.86 \mathrm{a}$ \\
\hline \multicolumn{5}{|c|}{ Carrot cultivars intercropped with cowpea-vegetable } \\
\hline Brasília & $7.74 \mathrm{a}^{*}$ & $12.23 \mathrm{a}$ & $1.84 \mathrm{~b}$ & $1.09 \mathrm{a}$ \\
\hline Alvorada & $3.74 \mathrm{~b}$ & $13.19 \mathrm{a}$ & $2.99 \mathrm{a}$ & $1.12 \mathrm{a}$ \\
\hline \multicolumn{5}{|c|}{ Carrot cultivars monocropped } \\
\hline Brasília & $12.74 \mathrm{a}$ & $19.11 \mathrm{a}$ & $1.17 \mathrm{a}$ & $2.07 \mathrm{a}$ \\
\hline Alvorada & $5.57 \mathrm{~b}$ & $19.83 \mathrm{a}$ & $1.94 \mathrm{a}$ & $0.71 \mathrm{~b}$ \\
\hline CV (\%) & 38.13 & 24.80 & 38.80 & 63.46 \\
\hline
\end{tabular}

*Means followed by different lowercase letters in the column differ statistically by Tukey's test at $5 \%$ probability.

Statistical differences were found between cultivars of cowpea-vegetable intercropped with carrot in the productivity of short roots in BRS Itaim, BRS Guariba, and Cauamé, exceeding productivity of BRS Tumucumaque, and between intercropped and monocropped carrot cultivars in productivity of long roots, with the cultivar Brasília achieving higher values than Alvorada, between intercropped carrot cultivars in the productivity of short roots, with the cultivar Alvorada obtaining higher values than the cultivar Brasília, and between monocropped carrot cultivars in the productivity of roots long and scrap, with the Brasilia cultivar showing higher values than the cultivar Alvorada (Table 3).

Higher productivities in terms of long roots and means were recorded both in the monocropping and intercropping systems. Commercial production of carrot roots in the intercropping system reached $94.99 \%$ of the total production, of which $26.14 \%$ were long roots, $57.88 \%$ medium roots, and $10.97 \%$ short roots. Carrot commercial production in the monocropping system yielded $95.59 \%$ of the total production, of which $28.99 \%$ were long roots, $61.69 \%$ medium-sized roots, and $4.91 \%$ short roots. This was probably due to the high fertilization efficiency of roostertree, in particular the amount of supplied potassium.

\section{Indices of agronomic/biological efficiency of the intercropping systems}

There were no significant interactions or statistical differences between treatment factors indicating agronomic/biological efficiency (Table 4).

Table 4. Mean values LER (using the average of replications of the cultivars in monocrop over blocks), productive efficiency index (PEI), and score of the $\mathrm{Z}$ canonical variable in combinations of cowpea-vegetable cultivars with carrot cultivars.

\begin{tabular}{lccc}
\hline $\begin{array}{l}\text { Cowpea-vegetable } \\
\text { cultivars } \begin{array}{c}\text { intercropped } \\
\text { with carrot }\end{array}\end{array}$ & LER & PEI & Z score \\
\hline BRS Itaim & $1.21 \mathrm{a}$ & $0.72 \mathrm{a}$ & $0.84 \mathrm{a}$ \\
BRS Tumucumaque & $1.25 \mathrm{a}$ & $0.87 \mathrm{a}$ & $0.84 \mathrm{a}$ \\
BRS Guariba & $1.58 \mathrm{a}$ & $0.86 \mathrm{a}$ & $0.98 \mathrm{a}$ \\
BRS Cauamé & $1.18 \mathrm{a}$ & $0.80 \mathrm{a}$ & $0.90 \mathrm{a}$ \\
\hline & Cultivars of carrot intercropped with cowpea-vegetable \\
\hline Brasília & $1.25 \mathrm{a}$ & $0.82 \mathrm{a}$ & $0.97 \mathrm{a}$ \\
Alvorada & $1.36 \mathrm{a}$ & $0.79 \mathrm{a}$ & $0.81 \mathrm{a}$ \\
\hline CV $(\%)$ & 22.93 & 15.37 & 24.38 \\
\hline
\end{tabular}

*Means followed by different lowercase letters in the column differ statistically by Tukey's test at 5\% probability. 
A. P. COSTA et al.

Table 5. Values of LER, productive efficiency index (PEI), and score of the $\mathrm{Z}$ canonical variable in combinations of cowpea-vegetable cultivars with carrot cultivars.

\begin{tabular}{lccc}
\hline \multicolumn{1}{c}{ Treatment } & LER & PEI & Z score \\
\hline BRS Itaim x Brasília & $1.12 \mathrm{a}$ & $0.68 \mathrm{a}$ & $0.77 \mathrm{a}$ \\
BRS Itaim x Alvorada & $1.26 \mathrm{a}$ & $0.75 \mathrm{a}$ & $0.90 \mathrm{a}$ \\
BRS Tumucumaque x Brasília & $1.23 \mathrm{a}$ & $0.89 \mathrm{a}$ & $1.06 \mathrm{a}$ \\
BRS Tumucumaque x Alvorada & $1.27 \mathrm{a}$ & $0.84 \mathrm{a}$ & $0.62 \mathrm{a}$ \\
BRS Guariba x Brasília & $1.50 \mathrm{a}$ & $0.86 \mathrm{a}$ & $0.96 \mathrm{a}$ \\
BRS Guariba x Alvorada & $1.65 \mathrm{a}$ & $0.85 \mathrm{a}$ & $1.01 \mathrm{a}$ \\
BRS Cauamé x Brasília & $1.11 \mathrm{a}$ & $0.87 \mathrm{a}$ & $1.08 \mathrm{a}$ \\
BRS Cauamé x Alvorada & $1.24 \mathrm{a}$ & $0.74 \mathrm{a}$ & $0.72 \mathrm{a}$ \\
\hline CV (\%) & 22.93 & 15.37 & 24.38 \\
\hline
\end{tabular}

*Means followed by different lowercase letters in the column differ statistically by Tukey's test at 5\% probability.

According to Geraldi (1983), the most effective combinations between species in intercropping systems are those with high complementation between cultivars (high overall effect of the intercropping).

Based on the LER values, cowpea-vegetable and carrot are companion crops and therefore use environmental resources and land area more efficiently. According to Willey (1990), the best results can be achieved when companion plants strengthen the degree of complementarity; if this is the case, the intercropping will produce higher yields than their respective monocrops.

In terms of productive efficiency index and score of the $\mathrm{Z}$ canonical variable, higher efficiency was observed in intercropping of cowpea-vegetables with carrot in the combinations of cowpea BRS Tumucumaque with Brasilia carrot and of BRS Cauamé with Brasilia carrot, respectively (Table 5), mainly due to low intraspecific competition among cultivars.

\section{Economic indicators of the intercropping systems}

There were no significant interactions or any statistical differences between treatment factors gross and net return, rate of return, profit margin, and modified monetary advantage (Table 6).

Table 6. Mean values of gross (GR) and net return (NR), rate of return (RR), profit margin (PM), and modified monetary advantage (MMA).

\begin{tabular}{|c|c|c|c|c|c|}
\hline $\begin{array}{l}\text { Cultivars of cowpea- } \\
\text { vegetable }\end{array}$ & $\begin{array}{c}\text { GR } \\
\left(\mathrm{RS} \mathrm{ha}^{-1}\right)\end{array}$ & $\begin{array}{c}\text { NR } \\
\left(\mathrm{RS} \mathrm{ha}^{-1}\right)\end{array}$ & $\mathbf{R R}$ & $\begin{array}{l}\text { PM } \\
(\%)\end{array}$ & $\begin{array}{c}\text { MMA } \\
\left(\mathrm{RS} \mathrm{ha}^{-1}\right) \\
\end{array}$ \\
\hline BRS Itaim & $22,552.06 \mathrm{a}^{*}$ & $8,772.75 \mathrm{a}$ & $1.63 \mathrm{a}$ & $38.11 \mathrm{a}$ & $1,522.96 \mathrm{a}$ \\
\hline BRS Tumucumaque & $26,153.59 \mathrm{a}$ & $12,374.29 \mathrm{a}$ & $1.90 \mathrm{a}$ & $45.11 \mathrm{a}$ & $2,720.86 a$ \\
\hline BRS Guariba & $26,843.85 \mathrm{a}$ & $13,064.55 \mathrm{a}$ & $1.94 \mathrm{a}$ & $47.57 \mathrm{a}$ & $4,874.84 \mathrm{a}$ \\
\hline BRS Cauamé & $23,900.73 \mathrm{a}$ & $10,121.43 \mathrm{a}$ & $1.73 \mathrm{a}$ & $40.10 \mathrm{a}$ & $1,743.75 \mathrm{a}$ \\
\hline \multicolumn{6}{|l|}{ Cultivars of carrot } \\
\hline Brasília & $25,614.43 \mathrm{a}$ & $11,907.45 \mathrm{a}$ & $1.86 \mathrm{a}$ & $45.15 \mathrm{a}$ & $2,428.94 \mathrm{a}$ \\
\hline Alvorada & $24,110.68 \mathrm{a}$ & $10,259.06 \mathrm{a}$ & $1.74 \mathrm{a}$ & $40.30 \mathrm{a}$ & $3,002.26 \mathrm{a}$ \\
\hline CV $(\%)$ & 17.32 & 38.85 & 17.22 & 25.23 & 100.92 \\
\hline
\end{tabular}

*Means followed by the same lowercase letters in the column do not differ statistically by Tukey's test at $5 \%$ probability.

The combination with the highest values of economic indicators was the cowpea cultivar BRS Tumucumaque with carrot Brasilia, and the largest modified monetary advantage was achieved with the combination of cowpea cultivar BRS Guariba with the carrot cultivar Alvorada (Table 7).

Table 7. Mean values of gross return (GR), net return (NR), rate of return (RR), profit margin (PM), and modified monetary advantage (MMA) in the intercropping systems of cowpea-vegetables with carrot.

\begin{tabular}{|c|c|c|c|c|c|}
\hline Treatment & $\begin{array}{c}\text { GR } \\
\left(\mathrm{RS} \mathrm{ha}^{-1}\right)\end{array}$ & $\begin{array}{c}\text { NR } \\
\left(\mathrm{RS} \mathrm{ha}^{-1}\right)\end{array}$ & $\mathbf{R R}$ & $\begin{array}{l}\text { PM } \\
(\%)\end{array}$ & $\begin{array}{c}\text { MMA } \\
\left({\left.\mathrm{R} \$ \mathrm{ha}^{-1}\right)}^{2}\right.\end{array}$ \\
\hline BRS Itaim x Brasília & $21,895.91$ & $8,188.93$ & 1.59 & 36.49 & $1,066.96$ \\
\hline BRS Itaim x Alvorada & $3,208.20$ & $9,356.58$ & 1.67 & 39.74 & $1,978.97$ \\
\hline BRS Tumucumaque x Brasília & $28,524.19$ & $14,817.21$ & 2.08 & 51.44 & $2,892.32$ \\
\hline BRS Tumucumaque x Alvorada & $23,782.99$ & $9,931.37$ & 1.71 & 38.77 & $2,594.41$ \\
\hline BRS Guariba x Brasília & $26,558.33$ & $12,851.35$ & 1.93 & 48.13 & $4,272.10$ \\
\hline BRS Guariba x Alvorada & $27,129.37$ & $13,277.75$ & 1.96 & 47.01 & $5,477.58$ \\
\hline BRS Cauamé x Brasília & $25,479.30$ & $11,772.32$ & 1.86 & 44.53 & $1,484.40$ \\
\hline BRS Cauamé x Alvorada & $22,322.16$ & $8,470.54$ & 1.61 & 35.66 & $1,978.96$ \\
\hline $\mathrm{CV}(\%)$ & 17.32 & 38.85 & 17.22 & 25.23 & 100.92 \\
\hline
\end{tabular}

Rev. Caatinga, Mossoró, v. 30, n. 3, p. 633 - 641, jul. - set., 2017 
In general, some combinations of cowpea-vegetables with carrot in intercropping systems enabled better use of environmental resources due to an effective interaction between inter- and intraspecific competition, increasing cultivar productivity. According to Grangeiro et al. (2007), this is possible when the species have different ecological niches, thus maximizing light use, absorption of nutrients and other resources.

\section{CONCLUSION}

The intercropping system using the cultivars BRS Guariba (cowpea) and Alvorada (carrot) achieved highest agronomic/biological efficiency. Highest economic efficiency was achieved with the combination BRS Tumucumaque (cowpea) and Brasilia (carrot).

The use of roostertree as a green manure source proved to be feasible in the intercropping system of cowpea-vegetables with carrot.

\section{ACKNOWLEDGEMENTS}

Special thanks are due to the Conselho Nacional de Desenvolvimento Cientifico e Tecnológico (CNPq) for financial support and to the research group that develops technologies for growing vegetables on family farms.

\section{REFERENCES}

ALMEIDA, A. E. S. et al. Eficiência agronômica do consórcio alface-rúcula fertilizado com flor-de-seda. Revista Caatinga, Mossoró, v. 28, n. 3, p. 79-85, 2015.

BEZERRA NETO, F. et al. Assessment of agroeconomic indices in polycultures of lettuce, rocket and carrot through uni - and multivariate approaches in semi-arid Brazil. Ecological Indicators, Amsterdam, v. 1, n. 14, p. 11-17, 2012.

BEZERRA NETO, F. et al. Performance produtiva de cenoura consorciada com caupi-hortaliça sob diferentes quantidades de flor-de-seda. In: CONGRESSO NACIONAL DE FEIJÃO CAUPI, 3, Recife. Anais... Recife: IPA, 2013. p. 1-5.

BEZERRA NETO, F.; GOMES, E. G.; OLIVEIRA, A. M. Produtividade biológica em sistemas consorciados de cenoura e alface avaliada através de indicadores agroeconômicos e métodos multicritério. Horticultura Brasileira, Brasília, v. 25, n. 3, p. 193-198, 2007.
EMPRESA BRASILEIRA DE PESQUISA AGROPECUÁRIA - EMBRAPA. BRS Itaim: cultivar de feijão-caupi com grãos tipo fradinho. Teresina: Embrapa Meio-Norte, 2009. (folder).

EMPRESA BRASILEIRA DE PESQUISA AGROPECUÁRIA - EMBRAPA. Centro Nacional de Pesquisas de Solos. Sistema Brasileiro de Classificação de Solos. 2. ed. Rio de Janeiro: Embrapa, 2006. 306p.

FERREIRA, D. F. Sisvar: a computer statistical analysis system. Ciência e Agrotecnologia, Lavras, v. 35, n. 6, p. 1039-1042, 2011.

FREIRE FILHO, F. R. et al. Melhoramento Genético. In: FREIRE FILHO, F. R.; LIMA, J. A. A.; RIBEIRO, V. Q. (Eds.). Feijão-caupi: avanços tecnológicos. Brasília: Embrapa Informação Tecnológica, 2005. cap. 1, 29-92.

FROTA, K. M. G. Composição química do feijão caupi (Vigna unguiculata (L.) Walp), cultivar BRS-Milênio. Ciência e Tecnologia de Alimentos, Campinas, v. 28, n. 2, p. 470-476, 2008.

GERALDI, I. O. Método de análise estatística para combinação de cultivares em consórcio. 1983. 120p. Tese (Doutorado em Agronomia: Área de Concentração em Genética e Melhoramento de Plantas) - Escola Superior Luiz de Queiroz da Universidade de São Paulo, SP, 1983.

GRANGEIRO, L. C. Produtividade da beterraba e rúcula em função da época de plantio em monocultivo e consórcio. Horticultura Brasileira, Brasília, v. 25, n. 4, p. 577-581, 2007.

LOPES, W. A. R. et al. Produtividade de cultivares de cenoura sob diferentes densidades de plantio. Revista Ceres, Viçosa, v. 55, n. 5, p. 482-487, 2008.

MATOS FILHO, C. H. A. et al. Potencial produtivo de progênies de feijão-caupi com arquitetura ereta de planta. Ciência Rural, Porta Alegre, v. 39, n. 2, p. 348-354, 2009.

MONTEZANO, E. M.; PEIL, R. M. N. Sistemas de consórcio na produção de hortaliças. Revista Brasileira de Agrociência, Pelotas, v. 12, n. 2, p. 129-132, 2006.

NOVAIS, R. F. et al. Fertilidade do solo. In: MEURER, E. J. Fatores que influenciam o crescimento e o desenvolvimento das plantas. Viçosa: SBCS, 2007. cap. 2, 65-90.

OLIVEIRA, L. J. Viabilidade agroeconômica do bicultivo de rúcula e coentro consorciado com cenoura em função de quantidades de jitirana $e$ 
densidades populacionais. 2012. 102 f. Tese (Doutorado em Fitotecnia: Área de Concentração em Agricultura Tropical) - Universidade Federal Rural do Semi-Árido, Mossoró, 2012.

ROCHA, M. de M. O feijão-caupi para consumo na forma de feijão fresco. 2009. Disponível em: $<$ http://agrosoft.com/pdf.php/?node=212374>. Acesso em: 31 jan. 2010.

SANTOS, J. F. et al. Novas variedades de caupi para a microrregião do Brejo Paraibano. Tecnologia \& Ciência Agropecuária, João Pessoa, v. 3, n. 3, p. 7-12, 2009.

SILVA, F. S. et al. Avaliação de cultivares de feijão-caupi irrigado para produção de grãos verdes em Serra Talhada - PE. Revista Caatinga, Mossoró, v. 26 n. 1, p. 21-26, 2013.

SILVA M. G. et al. Efeito da solarização, adubação química e orgânica no controle de nematóides em alface sob cultivo protegido. Horticultura Brasileira, Brasília, v. 24, n. 4, p. 489-494, 2006.

SILVA, R. C. P. Adubação verde com espécie espontânea no consórcio de cenoura e alface em bicultivo sob diferentes quantidades de biomassa e arranjos espaciais. 2014. 71 f. Dissertação (Mestrado em Fitotecnia: Área de Concentração em Agricultura Tropical) - Universidade Federal Rural do Semi-Árido (UFERSA), Mossoró-RN, 2014.

SOARES DE MELLO, J. C. C. B. et al. Análise de desempenho de sistemas de produção modais de pecuária de cria no Brasil. Produção, Niterói, v. 23, n. 4, p. 877-886, 2013.

SOARES DE MELLO, J. C. C. B.; GOMES, E. G. Eficiências aeroportuárias: uma abordagem comparativa com análise de envoltória de dados. Revista de Economia e Administração, São Paulo, v. 3, n. 1, p. 15-23, 2004.

VANDERMEER, J. H. The ecology of intercropping. Cambridge: Cambridge University Press, 1989. 237 p.

VIEIRA, F. A. Doses de máxima eficiência física e econômica de flor-de-seda no rendimento de caupi-hortaliça. 2014. 55f. Dissertação (Mestrado em Fitotecnia: Área de Concentração em Agricultura Tropical) - Universidade Federal Rural do SemiÁrido (UFERSA), Mossoró, 2014.

VIEIRA, J. V.; PERSOA, H. B. S. V.; MAKISHIMA, N. Cultivo da cenoura (Daucus carota L.). Brasília: Embrapa Hortaliças, 1997. 19 p. (Instruções Técnicas, 13).
WAKTOLA, S. K.; BELETE, K.; TANA, T Productivity evaluation of maize-soybean intercropping system under rain fed condition at Bench-Maji Zone, Ethiopia. Sky Journal of Agricultural Research, Nigeria, v. 3, n. 9, p. 158-164, 2014.

WILLEY, R. W. Resource use in intercropping systems. Agricultural Water Management, Amsterdam, v. 17, n. 1-3, p. 215-231, 1990. 